\title{
Long-term changes in intertidal estuarine diatom assemblages related to reduced input of organic waste
}

\author{
H. Peletier*
}

Rijkswaterstaat, National Institute for Coastal and Marine Management (RIKZ), PO Box 207, 9750 AE Haren, The Netherlands

\begin{abstract}
A comparison is made of the species composition and density of benthic diatoms of an intertidal brackish mudflat in the Ems-Dollard estuary (Netherlands/Germany) under conditions of high (1977 to 1980) and reduced (1987 to 1993) organic waste input from the river Westerwoldsche Aa. During the observation period (1977 to 1993) the epipelic diatom population on the mudflat was composed of only a limited number of species. From 1977 to 1980 , every year broadly the same spatial and temporal patterns of the sediment-inhabiting diatoms were found, viz. an alternating dominance of Navicula salinarum and $N$. pygmaea. In 1993 this pattern had disappeared and $N$. phyllepta and $N$. flanatica, species with a lower tolerance to high ammonium and sulphide concentrations, were the dominant species. This change could be attributed to a reduction of organic waste input. The declining abundance of $N$. pycymaea was probably also partly caused by the decreased abundance of the nematode Eudiplogastor pararmatus, an indicator of organic enrichment. In 1987 and 1993, the diatom populations on the mudflat showed density maxima in spring and late autumn, in contrast with the period 1976 to 1977, during which values were high (over $100 \mathrm{mg}$ chlorophyll a m $\mathrm{m}^{-2}$ ) during a large part of the year, not showing any spring or autumn bloom. The difference in the development of microphytobenthos biomass was probably caused by the increasing numerical densities of the macrofaunal diatom grazers Nereis diversicolor and Corophium volutator, caused by the reduction of the organic waste.
\end{abstract}

KEY WORDS: Estuarine diatoms · Organic pollution · Ems-Dollard estuary · Grazing

\section{INTRODUCTION}

Well-developed benthic diatom populations can be found in the South East Dollard, an estuarine embayment of the Dutch Wadden Sea (Fig. 1). These sediment-inhabiting diatoms are the most important primary producers and play a key role in the intermingling of benthic and pelagic food chains. The distribution of such diatom populations has been related to physical factors such as gradients in salinity, elevation, temperature, organic pollution, grazing and sediment characteristics (McIntire 1978, Colijn \& Dijkema 1981, Admiraal 1984, Amspoker \& McIntire 1986, Kosugi 1987, Oppenheim 1988, On \& Koh 1995).

From 1970 to 1980 enormous amounts of organic waste from potatoflour and cardhoard industries were

\footnotetext{
·E-mall: peletier@rikz.rws.minvenw.nl
}

discharged through the river Westerwoldsche Aa (WWA) into the southeast of the Dollard (Fig. 2). As a result, during this period, mainly in autumn and early winter, a large area of tidal flats was flooded with water at less than $20 \%$ oxygen saturation (Van Es et al. 1980) In the vicinity of the outfall, this led to a strongly decreased population diversity of meio- and macrofauna on the tidal flats. The discharge of polluted fresh water from the river WWA caused a steep gradient in salinity and in reduced conditions in the mudflat sediment. Sulphide and ammonium were present in appreciable toxic quantities in the anaerobic layers of the sediment. In the same period, the sediment-inhabiting diatoms showed recurrent seasonal succession patterns from year to year These succession patterns appeared to be caused at least nartly by selective pressure by the extreme conditions of their habitat (Admiraal et al. 1984).

Since 1982, the organic waste input has been significantly reduced (by ca $70 \%$ ) due to a sanitation 


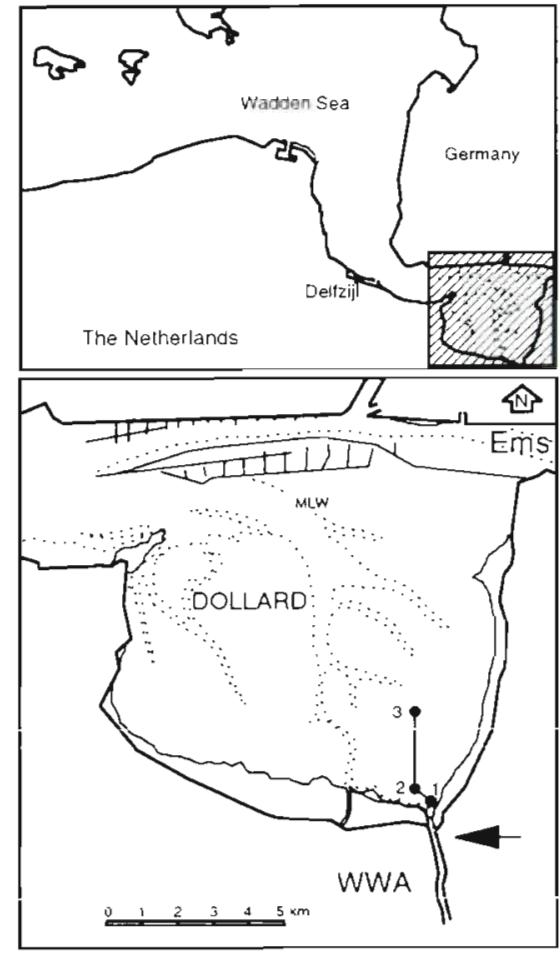

Fig. 1. Map of the Ems-Dollard estuary, showing the transect $(\bullet)$ on the intertidal mudflat in the Dollard and the discharge point (arrow) of the river Westerwoldsche Aa (WWA) $\mathrm{MLW}=$ line of mean low water

scheme executed by the industries concerned (Fig. 2). The reduction of waste discharges decreased environmental stress factors such as the exposure to reduced conditions on the mudflat surface. In 1991, as a last step in the sanitation scheme, a large purification plant came into operation, further reducing the waste load discharged into the Dollard significantly (Fig. 2A).
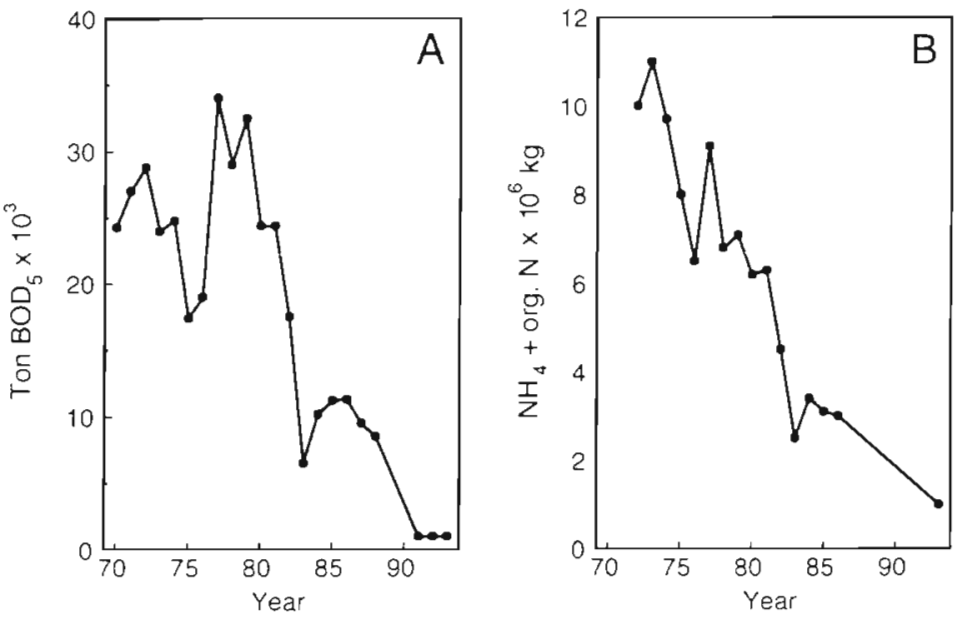

Fig. 2. (A) Total. waste discharges (measured $a s \mathrm{BOD}_{5}$ ) and (B) ammonia and organic $N$ discharges from the river WWA into the Ems-Dollard estuary during August to April in the period 1970 to 1993
This study describes the spatial and temporal variation in species composition of the epipelic diatom populations on the mudflat under these changing conditions. This offers the opportunity to verify some of the conclusions of Admiraal et al. (1984) on the factors regulating these communities. These stress factors included low or high salinity, high concentrations of ammonia and free sulphide, and high temperatures The relationships with the benthic fauna will also be discussed.

\section{MATERIALS AND METHODS}

Study area. The mudflat studied is located in the inner part of the Ems-Dollard estuary, a part of the Dutch-German Wadden Sea (Fig. 1). A transect over the mudflat, with 3 stations at distances of $0.8,1.2$ and $3.2 \mathrm{~km}$ from the discharge point, was investigated in 1987 and 1993. The same transect was investigated in the period 1977 to 1980 (Admiraal et al. 1984). The soft sediments of the mudflat were very muddy and rich in

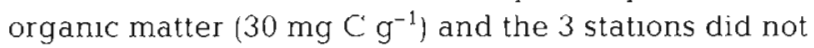
show appreciable differences in elevation. The level of the mudflat is about $1 \mathrm{~m}$ above mean sea level. For more characteristics see Admiraal \& Peletier (1980). In the period 1970 to 1981 , these stations were flushed with organically polluted waste water discharged from the river WWA, particularly during the working season of the Dutch potato starch industry (September to December). River water was sluiced out during low water. Between 1970 and 1981, in October, November and December, this polluted water contained about $200 \mathrm{mg}$ organic $\mathrm{C}^{-1}$ and 1.5 to $3 \mathrm{mM}$ of ammonium. During the rest of the year these values were ca $50 \mathrm{mg}$ $\mathrm{C}^{-1}$ and 0.1 to $0.5 \mathrm{mM}$ of ammonium (Admiraal \& Peletier 1980). The dispersal of the river water over the estuary is irregular and depends on tidal currents and wind, but the 2 stations (1 and 2) in the vicinity of the mouth of the river WWA were mostly affected by the river discharge as was substantiated by observations of a salinity gradient. The discharge of organic waste was responsible for a gradient in the depth of the aerobic top layer of the sediment along the station transect.

Density and species composition of diatoms. The density of microphytobenthos on the mudflat was measured both as chlorophyll a (chl a) concentration and by counting the numbers of living cells in the top $0.5 \mathrm{~cm}$ of the sediment. In 1987 and 1993, the transect was sampled monthly during low tide. At Stn 2, 8 sediment cores (diameter $2.4 \mathrm{~cm}$ ) were collected at random. The upper $0.5 \mathrm{~cm}$ 
of 4 cores were pooled and extracted in $90 \%$ aqueous acetone and the chl a concentration was determined spectrophotometrically according to Lorenzen (1967). This method was the same as used on the mudflat in 1976 and 1977 (Colijn \& De Jonge 1984).

The top $0.5 \mathrm{~cm}$ of the other 4 sediment cores were pooled, mixed and diluted 10 -fold with artificial seawater. The numbers of living epipelic diatoms in this suspension were counted in a microscope counting chamber (Neubauer, improved, $0.1 \mathrm{~mm}$ deep) under epifluorescent light.

For analysis of the diatom flora, sediment samples ( 3 to $4 \mathrm{~mm}$ ) were scraped from the tidal flat at Stns 1 . 2 and 3 . The species composition of the epipelic diatom populations was determined using tissue-harvested samples (Eaton \& Moss 1966) that were mounted in highly refractive resin after oxidation in hydrogen peroxide. In each sample, 200 to 500 frustules were identified. The relative abundance of the species was expressed as percentage of the total number of frustules identified. Microscopic comparison of tissueharvested diatom populations with living samples scraped directly from the sediment of the mudflat did not indicate that the lens-tissues selectively harvested only a limited number of species. Large and intermediately sized cells of the epipelion were abundant on these muddy sediments. Undisturbed sediment cores collected from the emersed mudflat during the day in 1979 at Stns 2 and 3 showed more than $90 \%$ of the epipelic diatom population to be present in the upper $5 \mathrm{~mm}$ (Admiraal et al. 1982).

Chemical analyses. Sediment cores of the mudflat ( 3 to $4 \mathrm{~mm}$ thick) taken at low tide were transferred to the laboratory and immediately centrifuged to separate sediment and interstitial water. After filtration through glassfiber filters $(\mathrm{GF} / \mathrm{C})$ the salinity of interstitial water was measured using a conductivity meter (WTW LF 191).

\section{RESULTS}

\section{Changes in environmental conditions}

During the period of high waste discharge between 1976 and 1980, Stns 1 and 2 were covered with superficial black sediment layers. In 1993, the thickness of the aerobic top layer on these stations, based on visible inspection, had increased to $3-4 \mathrm{~cm}$ due to the reduction of the amount of organic waste. Recent microelectrode measurements, however, indicate that within the light coloured, so-called oxidised, aerobic layer, $\mathrm{O}_{2}$ may reach zero values (Jørgensen
\& Revsbech 1989). The amount of ammonium discharged had also decreased (Fig. 2B).

The average monthly fresh water discharge in 1993 was much lower than in 1979 and 1980 due to changed water management (Fig. 3A). This increased salinities of the interstitial water at Stns 1 (Fig. 3B) and 2 (not shown) during the year. The salinity in the period 1979 to 1980 at Stns 1,2 and 3 was 0.5 to $2.0,0.5$ to 7.5 and 2.5 to $14.2 \%$, respectively. In 1993 the salinity at Stns 1,2 and 3 was similar, varying between 2.5 and $15 \%$, and showed the same seasonal patterns, so the difference between the stations had decreased. As interstitial salinity is rather well correlated to the monthly variation in freshwater discharge (Fig. 3), it is not very likely that the values measured were much influenced by evaporation or rainfall during the short period of tidal emergence before sampling.

\section{Changes in diatom density}

In 1987 and 1993, the density of diatom populations (measured as chl a) at Stn 2 showed maxima in spring and late autumn with a distinct summer depression (Fig. 4). This is in contrast with the period of high waste loads (1976 to 1977) during which the chl a values were high (over $100 \mathrm{mg} \mathrm{m}^{-2}$ ) during a large part of the year without showing any spring or autumn bloom.

\section{Changes in species composition}

Fig. 5 presents the temporal patterns of relative abundance of diatom species in 1977, 1987 and 1993 at the 3 stations of the mudflat transect. Relative abun- 


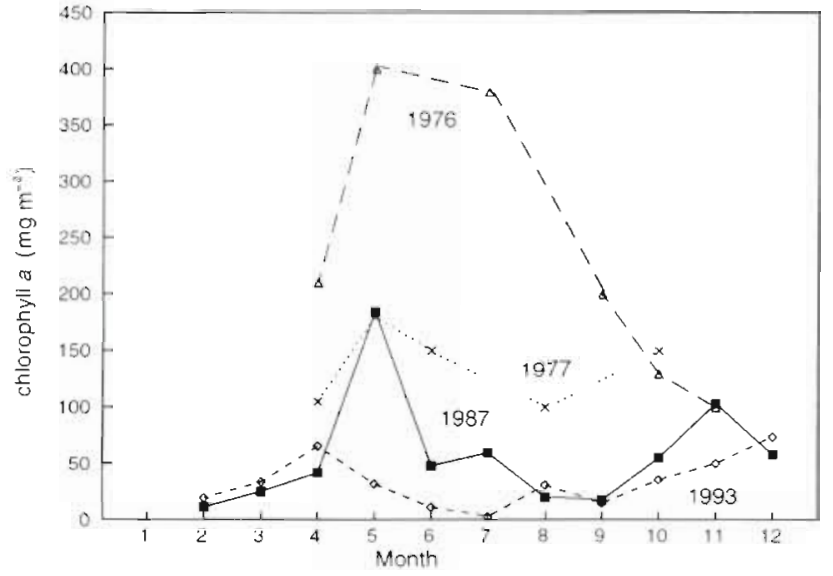

Fig. 4. Standing stock of diatom populations, measured as chlorophyll $a$ in the top $0.5 \mathrm{~cm}$ of the sediment, on the intertidal mudflat at Stn 2 in 1976, 1977, 1987 and 1993. Data for 1976-1977 from Colijn \& De Jonge (1984) dance of species is expressed as percentage of total cell numbers of the diatom populations. This relative abundance does not necessarily reflect the abundance in absolute cell numbers, since the population density varies strongly over the seasons (Fig. 6). From 1977 to 1980, every year showed broadly the same temporal patterns to be present at each of the stations (Admiraal et al. 1984). In each of these years, the epipelic diatom populations on the mudflat transect were composed of only a limited number of species. At Stn 1, monocultures of the species Navicula salinarum Grunow were found and in summer $N$. pygmaed Kützing became dominant. Nitzschia sp. was restricted to summer, whereas Navicula cryptocephala Kützing and Navicula phyllepta Kützing were present in all seasons. The abundance of Navicula flanatica Grunow was very low and restricted to winter. In spring 1987 , the abundance of $N$. flanatica at Stns 1 and 2 had in-
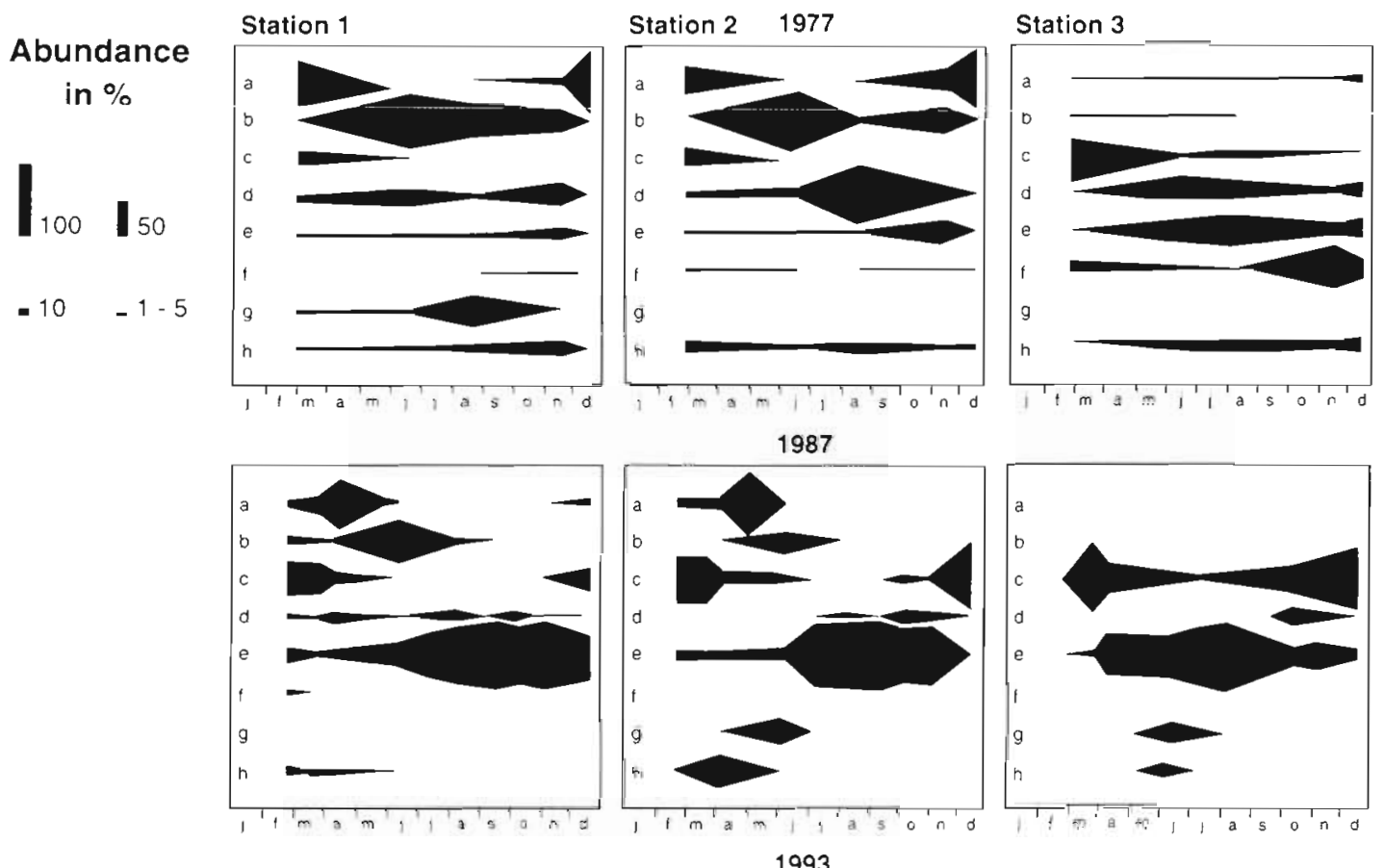

1987
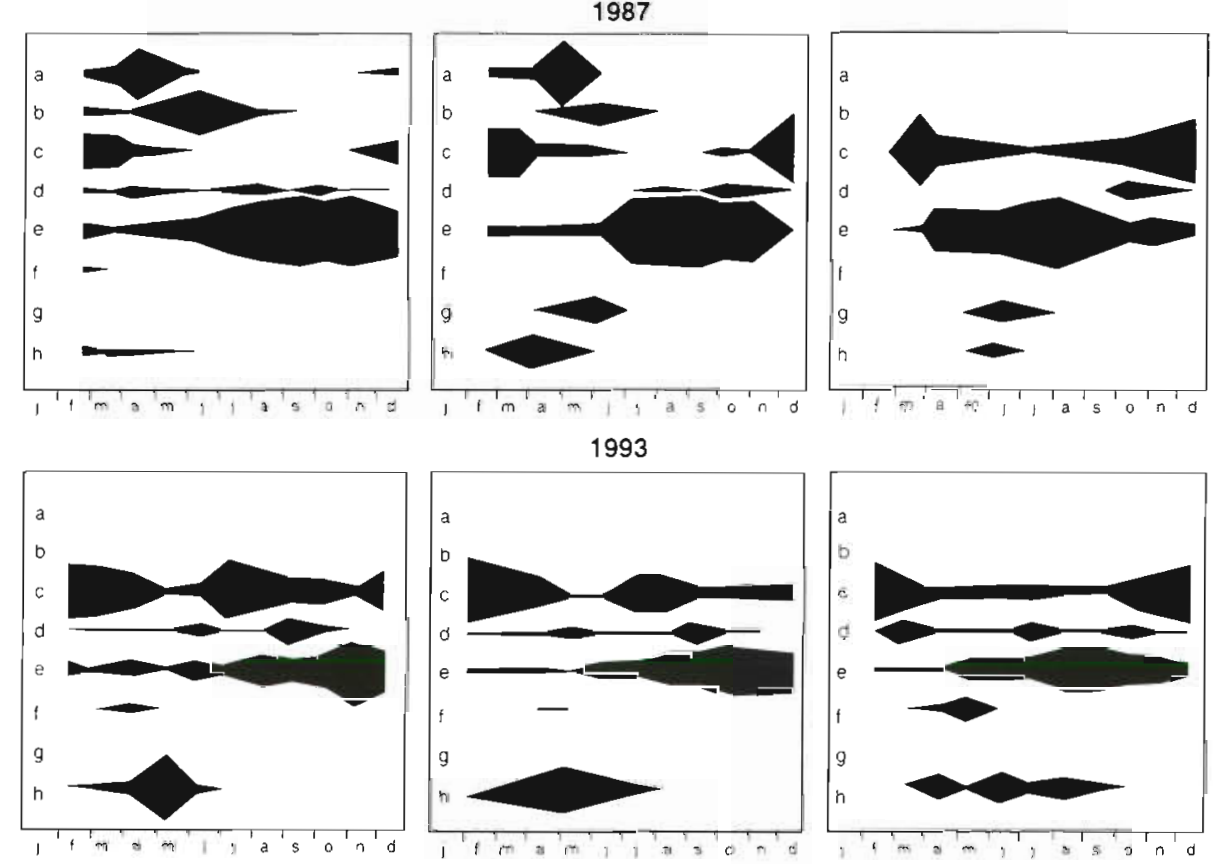

1993
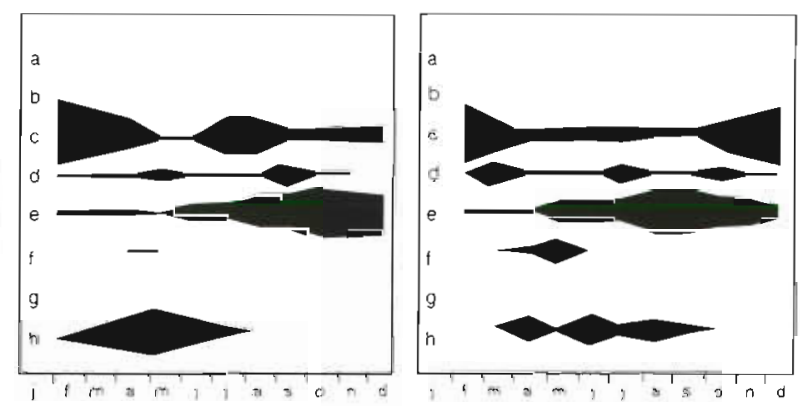

Fig. 5. Seasonal changes in the relative abundance of diatom species at Stns 1, 2 and 3 in 1977, 1987 and 1993. Abundance expressed as percentage of the total number of cells identified. $\mathrm{a}=N$ dvicula salinarum; $\mathrm{b}=N$. pygmaea; $\mathrm{c}=N$. flanatica; $\mathrm{d}=\mathrm{N}$. cf. cryptocephala; $\mathrm{e}=N$. phyllepta $\mathrm{f}=$ Gyrosigma fasciola $\mathrm{g}=$ Nitzschia spp $; \mathrm{h}=$ other species 


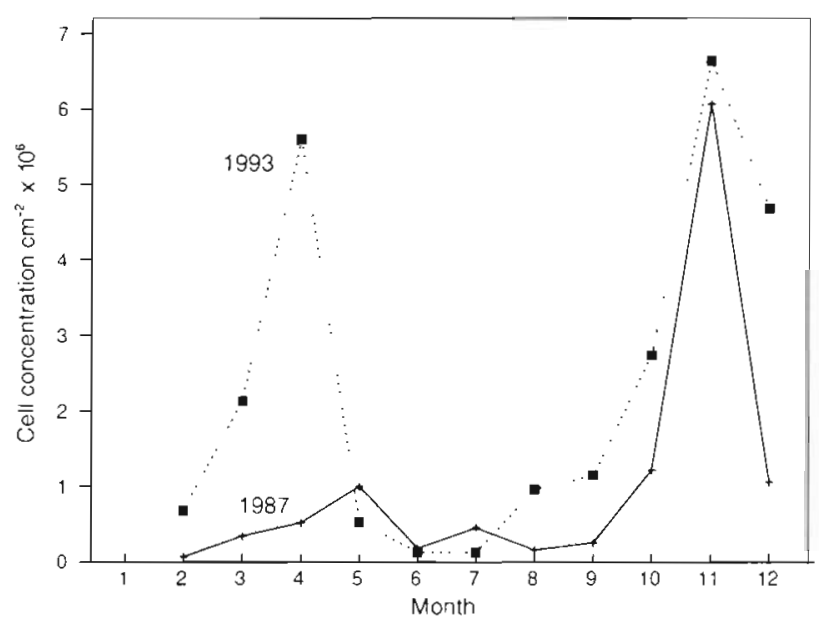

Fig. 6. Diatom cell concentration in the $10 \mathrm{p} 0.5 \mathrm{~cm}$ sediment of the intertidal mudflat at $\operatorname{Stn} 2$ in 1987 and 1993

creased. Until June the dominance of $N$. salinarum and $N$. pygmaea alternated; later in the year a nearmonoculture of $N$. phyllepta was found. The density of $N$. cryptocephala was very low throughout the year.

In 1993, the alternating dominance of Navicula salinarum and $N$. pygmaea at Stns 1 and 2 had disappeared. In this year, $N$. phyllepta and $N$. flanatica became the most abundant species. In May 1993, at Stn 1, Amphora coffeaeformis Agardh was the most abundant species with values up to $90 \%$ (Fig. 5; group ' $h$ ')

At Stn 3 ( $3.2 \mathrm{~km}$ from the mouth of the river WWA), the dominant species in the period 1977 to 1980 were Navicula flanatica, $N$. phyllepta, $N$. cryptocephala and Gyrosigma fasciola (Ehr.) Cleve. N. flanatica and $G$. fasciola were restricted to winter, whereas $N$. cryptocephala and $N$. phyllepta were found throughout the year. In contrast to Stn 1 and 2, the abundance

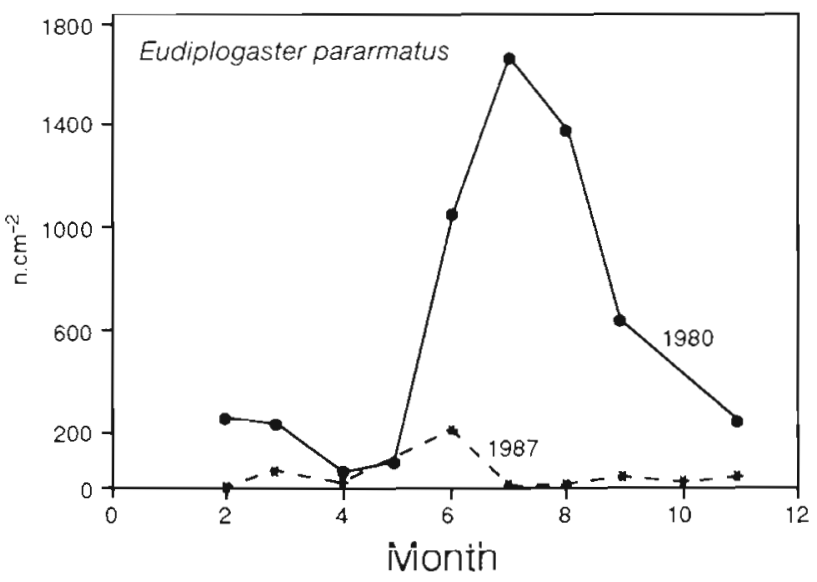

Fig. 7. Eudiplogaster pararmatus. Numerical density at $\mathrm{Stn} 2$ in 1980 and 1987. Data from Essink \& Romeyn (1994) of $N$. salinarum and $N$. pygmaea was very low in this period. In 1993, these 2 species were not found any more. Furthermore, at Stn 3, Pleurosigma angulatum (Quek.) W. Smith, Diploneis bombus (Ehr.) Cleve, Stauroneis amphioxys Greg. and Nitzschia apiculata (Greg.) Grunow ('other species') had increased in 1993 compared to the earlier years. In 1987 and 1993, N. flanatica was present during summer at Stns 1, 2 and 3 . This is in contrast to the period 1977 to 1980 (see Fig. 5).

\section{DISCUSSION AND CONCLUSION}

\section{Selective factors for benthic diatom species}

In previous studies (Admiraal \& Peletier 1979, 1980) various stress factors, such as high concentrations of free sulphide and ammonia and low or high salinity, had been indicated as regulators of the species composition of diatom populations. High sulphide concentrations were tolerated only by Navicula salinarum and $N$. pygmaea; $N$. phyllepta and $N$. flanatica were somewhat less tolerant. Observations showed a high ammonium tolerance in $N$. salinarum and somewhat less in N. pygmaea cultures (Admiraal \& Peletier 1980). The importance of ammonium as a selective factor in the benthic diatom population was also found by Sullivan (1978) and Van Raalte et al. (1976).

The alternating dominance of Navicula salinarum and $N$. pygmaea at Stns 1 and 2 in 1977 to 1980 was probably caused by the waste water discharge because the alternation of biological data and environmental conditions is very much in line with expectations on the basis of the experimental analyses (Admiraal \& Peletier 1980). Moreover, in 1993, species with a lower tolerance to high ammonium and sulphide concentrations had become dominant at Stns 1 and 2 .

Due to the modification in the discharge scheme for the river WWA, caused by the employment of a new sluice complex, the salinity of the interstitial water increased in 1992 and 1993, especially in spring and summer. Admiraal \& Peletier (1980) showed that Navicula salinarum can predominate only at the lower limit of its salt tolerance (ca $1 \%$ ). The photosynthetic capacity of a population dominated by $N$. phyllepta showed a low tolerance to salinities of $<2 \%$ (Admiraal \& Peletier 1980). These experimental results provide an explanation for the disappearance of $N$. salinarum from Stns 1 and 2 and the dominance in 1993 of $N$. phyllepta. High salinity, however, did not cause changes in the species composition of diatoms (Admiraal \& Peletier 19801

Hopkins (1964) and Admiraal (1984) considered high temperature as a selective factor responsible for the disappearance of Navicula flanatica in summer. In 
contrast to this, after a dominance in spring, this species remained present at Stns 1, 2 and 3 throughout the year 1993. So, other factors must be regulating here. The selection mechanisms reported by Admiraal (1984) explain very well the distribution patterns of benthic diatoms and changes therein, especially at Stns 1 and 2. These distribution patterns seem to be governed by the diminishing waste load and the changing discharge scheme of the river WWA. Therefore, it is concluded that the abovementioned selective factors (cf. Admiraal 1984) are much more important than changing weather conditions which cause higher temperatures, desiccation, etc.

\section{Regulation of microphytobenthic biomass}

Large changes in the seasonal development of microphytobenthic biomass were observed during the reduction of organic loading of the mudflat (see Fig. 4). The overall decrease of biomass may have been caused by an increased rate of consumption by benthic faurid. Edrier studies, however, indicaled ind grazing by dense nematode populations was not capable of causing the summer depression in the diatom population (Admiraal et al. 1983). The same transect was also used to investigate meiofauna (Bouwman et al. 1984, Essink \& Romeyn 1994). In 1980, close to the river WWA (Stn 1), the nematode association was dominated by only 2 species: Eudiplogaster pararmatus and Dichromadora geophyli. E. pararmatus feeds on diatoms, but Navicula pygmaea was not consumed easily due to the greater mechanical resistance of these diatoms to puncturing by the nematodes (Romeyn et al. 1983). As a consequence, E. pararmatus contributed rather to the abundance of $N$. pygmaea in summer 1977 (at Stns 1 and 2; cf. Fig. 5). In 1987, the abundance of E. pararmatus at Stn 2 of the mudflat had decreased considerably (Fig. 7; Essink \& Romeyn 1994). Furthermore, the herbivorous meiofauna had become more diverse, having a lower food selectivity, obviously resulting in the declining abundance of $N$. pygmaea in summer 1987.

Increasing macrofauna density following the reduction of organic waste load (Essink et al. 1985, Esselink et al. 1989) probably also contributed to a declining standing stock of diatoms in summer. Although grazing by benthic macrofauna is well known (Andersen. \& Kristensen 1988, Gould \& Gallagher 1990), little is known about the rate of grazing. In 1974 and 1975 the macrofauna in the area near the mouth of the river WWA was nearly absent; only low numbers of the ragworm Nereis diversicolor, the tellinid bivalve Macoma baltica and the amphipod Corophium volutator were present (Van Es et al. 1980). In 1979, specimens of
$N$. diversicolor occurred occasionally, but during the waste discharge in autumn these worms completely disappeared from an area within 2 to $3 \mathrm{~km}$ from the mouth of the river WWA (BOEDE 1985, Essink et al. 1985). From 1982 to 1985 the numerical density of $N$ diversicolor slightly increased in this area (Essink et al. 1985, Esselink et al. 1989). Compared with earlier years the results of a survey of the macrobenthic fauna of the Ems-Dollard estuary carried out in June-July 1985 also showed a increasing density of $C$. volutator (ca 100 ind $\mathrm{m}^{-2}$ ) and $M$. baltica (ca 50 to 250 ind. $\mathrm{m}^{-2}$; Essink et al. 1987). In 1993, the densities of $N$. diversicolor, $C$. volutator and $M$. baltica had further increased up to 4000,1500 and 100 ind. $\mathrm{m}^{-2}$, respectively (Weber 1993). Thus, in the period 1975 to 1993 the macrofauna species composition did not change very much. The species abundance, however, increased considerably.

On this intertidal mudflat Nereis diversicolor is probably primarily a deposit feeder due to the presence of only a thin layer of surface water covering the flat during tidal exposure that restricts possibilities for filter feeding. So in this area several macrofauna species for which sediment-inhabiting diatoms are the main food resource (Goerke 1966, Esselink et al. 1989, Kamermans 1994) have increased, providing an explanation for the decrease in the microphytobenthos standing stock.

In 1988, near the mouth of the WWA a very high density of the recently introduced North American spionid polychaete Marenzelleria viridis was present (Essink \& Kleef 1993). M. viridis is a selective depositfeeder (Whitlatch 1980, Dauer et al. 1981). A pair of tentaculate palps is used for the collection of preferably small sediment particles. This polychaete may also eat benthic diatoms and, therefore, may also have contributed to the observed decrease of microphytobenthos.

The increased species diversity in both benthic diatoms (this study) and nematodes (Essink \& Romeyn 1994) and the increased macrobenthos density (Essink et al. 1985, Esselink et al. 1989, Weber 1993) is a consequence of the sanitation scheme that greatly reduced organic loading of the Dollard.

Acknowledgements. I thank Dr K. Essink and Prof. W. Admiraal for their critical comments on the manuscript. I am grateful to Dr G. C. Cadée for many helpful comments.

\section{LITERATURE CITED}

Admiraal W (1984) The ecology of estuarine sedumentinhabiting diatoms. In: Round FE, Chapman DJ (eds) Progress in phycological research 3. Biopress Ltd., Bristol, p 232-269

Admiraal W, Bouwman LA, Hoekstra L, Romeyn K (1983) Qualitative and quantitative interactions between micro- 
phytobenthos and herbivorous meiofauna on a brackish intertidal mudflat. Int Rev Ges Hydrobiol 68(2):175-191

Admiraal W, Peletier H (1979) Sulphide tolerance of benthic diatoms in relation to their distribution in an estuary. Br Phycol J 14:185-196

Admiraal W, Peletier H (1980) Distribution of diatom species on an estuarine mudflat and experimental analyses of the selective effect of stress. J Exp Mar Biol Ecol 46:157-175

Admiraal W. Peletier H, Brouwer T (1984) The seasonal succession patterns of diatom species on an intertidal mudflat: an experimental analysis. Oikos 42:30-40

Admiraal W, Peletier H, Zomer $H$ (1982) Observations and experiments on the population dynamics of epipelic diatoms from an estuarine mudflat. Estuar Coast Shelf Sci $14: 471-487$

Amspoker 1:1C, McIntire CD (1986) Effects of sedımentary processes and salinity on the diatom flora of the Columbia River estuary. Botanica Mar 29(5):391-399

Andersen FO, Kristensen E (1988) The influence of macrofauna on estuarine benthic community metabolism: a microcosm study. Mar Biol 99:591-603

BOEDE (1985) Biological research Ems-Dollard estuary. Rijkswaterstaat Communications No. 40/1985. Rijkswaterstad, The Hague

Bouwman LA, Romeyn K, Admiraal W (1984) On the ecology of meiofauna in an organically polluted estuarine mudflat. Estuar Coast Mar Sci 19:1-17

Colijn F, De Jonge VN (1984) Primary production of microphytobenthos in the Ems-Dollard estuary. Mar Ecol Prog Ser 14:185-196

Colijn F, Dijkema KS (1981) Species composition of benthic diatoms and distribution of chlorophyll $a$ on an intertidal flat in the Dutch Wadden Sea. Mar Ecol Prog Ser 4:9-21

Dauer DM. Maybury CA, Ewing RM (1981) Feeding behaviour and general ecology of several spionid polychaetes from the Chesapeake Bay. J Exp Mar Biol Ecol 54:21-38

Eaton JW, Moss B (1966) The estimation of numbers and pigment content in epipelic algal populations. Limnol Oceanogr 11:584-595

Esselink P, Van Belkum J, Essink K (1989) The effect of organic pollution on local distribution of Nereis diversicolor and Corophium volutator. Neth J Sed Res 23(3): $323-332$

Essink K, Kleef HL (1993) Distribution and life cycle of the North American spionid polychaete Marenzelleria viridis (Verrill, 1873) in the Ems estuary. Neth J Aquat Ecol $27(2-4): 237-246$

Essink K, Kleef HL, Visser W, Tydeman P (1985) Population dynamics of the ragworm Nereis diversicolor in the Dollard (Ems Estuary) under changing conditions of stress by organic pollution. In: Gray JS, Christiansen ME (eds) Marine biology of polar regions and effects of stress on marine organisms. John Wiley \& Sons, Chichester, p $585-600$

Essink K, Romeyn K (1994) Estuarine nømatodes as indicators of organic pollution; an example from the Ems estuary (the Netherlands). Neth J Aquat Ecol 28(2):213-219

Essink K, Visser W, Begeman D (1987) Survey of macroscopic

This article was submitted to the editor zoobenthos in the Dollard; June-July 1985. Rijkswaterstaat, National Institute for Coastal and Marine Management, Report GWAO-87.155. Rijkswaterstaat, Haren (in Dutch)

Goerke H (1966) Nahrungsfiltration von Nereis diversicolor O. F. Müller (Nereidae, Polychaeta). Veröff Inst Meeresforsch Bremerh 10:49-58

Gould MD, Gallagher ED (1990) Field measurement of specific growth rate, biomass, and primary production of benthic diatoms of Savin Hill Cove, Boston. Limnol Oceanogr 35(8): 1757-1770

Hopkins JT (1964) A study of the diatoms of the Ouse estuary, Sussex Ill. The seasonal variation in the littoral epiphyte flora and the shore plankton. J Mar Biol Ass UK 44: $613-644$

Jorgensen BB, Revsbech NP (1989) Oxygen uptake, bacterial distribution, and carbon-nitrogen-sulfur cycling in sediments from the Baltic Sea-North Sea transition. Ophelia 31:29-49

Kamermans P (1994) Similarity in food source and timing of feeding in deposit- and suspension-feeding bivalves. Mar Ecol Prog Ser 104:63-75

Kosugi $M$ (1987) Limiting factors on the distribution of benthic diatoms in coastal regions-salinity and substratum. Diatom 3:21-31

Lorenzen CJ (1967) Determination of chlorophyll and pheopigments: spectrophotometric equations. Limnol Oceanogr 12:343-346

McIntire CD (1978) The distribution of estuarine diatoms along environmental gradients, a canonical correlation. Estuar Coast Mar Sci 6:447-457

Oh SH, Koh CH (1995) Distrubution of diatoms in the surficial sediments of the Mangyung-Dongjin tidal flat, west coast of Korea (Eastern Yellow Sea). Mar Biol 122:487-496

Oppenheim DR (1988) The distribution of epipelic diatoms along an intertidal shore in relation to principal physical gradients. Botanica Mar 31:65-72

Romeyn K, Bouwman LA, Admiraal W (1983) Ecology and cultivation of the herbivorous brackish-water nematode Eudiplogaster pararmatus. Mar Ecol Prog Ser 12:145-153

Sullivan MJ (1978) Diatom community structure: taxonomic and statistical analysis of a Mississippi salt marsh. J Phycol $14: 486-475$

Van Es FB, Van Arkel MA, Bouman LA, Schröder HGJ (1980) Influence of organic pollution on bacterial, macrobenthic and meiobenthic populations in intertidal flats of the Dollard. Neth J Sea Res 14(3/4):288-304

Van Raalte CD, Valiela I. Tral JM (1976) The effect of fertitization on the species composition of salt marsh diatoms. Wat Res 10:1-4

Weber S (1993) Response of four macrobenthos species to reduced organic waste input into the Dollard. Rijkswaterstaat, National Institute for Coastal and Marine Management. Working document RIKZ/OS-94.605x. Rijkswaterstaat, Haren (in Dutch)

Whitlatch RB (1980) Patterns of resource utilization and coexistence in marine intertidal deposit-feeding communities. J Mar Res 38:743-766

Manuscript first received: June 20, 1995

Revised version accepted: February 26, 1996 